\title{
ENVIRONMENTAL ASPECTS OF THE CONSTRUCTION INDUSTRY DEVELOPMENT IN LATVIA
}

\author{
Linda KAUŠKALE ${ }^{1}$, Ineta GEIPELE ${ }^{2}$, Jānis VANAGS ${ }^{3}$, \\ Natalija LEPKOVA ${ }^{4}$ \\ ${ }^{1-3}$ Institute of the Civil Engineering and Real Estate Economics, Riga Technical \\ University, 6 Kalnciema Str., Riga, LV-1048, Latvia \\ ${ }^{4}$ Department of Construction Management and Real Estate, Vilnius Gediminas Technical \\ University, Sauletekio Al. 11, LT-10223, Vilnius, Lithuania \\ Corresponding author e-mail: Linda.Kauskale@rtu.lv
}

\begin{abstract}
The importance of environmental aspects in construction is growing during the time. The aim of the research is to analyze environmental aspects of construction industry development and related regulations in Latvia, including the last green building certification development tendencies. The analysis, historical, document review and logical access methods have been used in the research. The article also includes overview of the international experience. The results of research show growing importance of environmental aspects in construction process and the necessity for market participants and industry development to consider them.
\end{abstract}

Keywords: Construction, environment, green building certification, green buildings, Latvia, real estate market, sustainability.

\section{INTRODUCTION}

Green building development is important at all levels. Green building analysis at the international level was analyzed by many scientists (Mattoni et al., 2018; Reed, R. G.,Krajinovic-Bilos, \& Reed, M. A. J., 2017; Tambovceva, Geipele, I., Geipele, S., 2011), importance of housing renovation and its problems were analyzed by Šnīdere, Geipele, Stāmure (2017), green neighborhood was analyzed by Tam et al. (2018). Practical aspects of sustainable construction in Latvia were analyzed by Stāmure, Kamola and Geipele (2015), planning and management problems of energy efficiency planning were analyzed by Actiņa, Geipele, Zeltiņš (2015). Environmental aspects of construction and sustainable real estate market development aspect were analyzed in the previous research as well (Kauškale et al., 2017; Kauškale et al., 2016, Kauškale, Geipele, 2017; Kauškale, Geipele, Riemenschneider, 2016; Kauškale, Riemenschneider, 2016). The aim of the present research is to analyze environmental aspects of construction industry development and related regulations in Latvia, including the last green building certification development tendencies. The object of research is construction industry. The subject of research is green building development in Latvia. The analysis, historical, document review and logical access methods have been used 
in the research. The research includes the overview of international experience and the latest tendencies of green building development in Latvia.

\section{GENERAL REGULATIONS AND PROBLEM OVERVIEW}

Sustainability aspects are considered in the world in different areas and at different levels. For instance, sustainability aspects of Olympic Games were considered in RIO Olympic Games Sustainability Management Plan (published in 2013) and Tokyo Olympic and Paralympic Games High-level Sustainability Plan (published in 2016), as shown in Table 1. These plans included a variety of aspects connected with sustainable development.

Table 1. Rio Olympic Games Sustainability Management Plan (2013) and Tokyo

Olympic and Paralympic Games High-Level Sustainability Plan (The Tokyo Organising Committee of the Olympic and Paralympic Games, 2016) [developed by authors]

\begin{tabular}{|c|c|}
\hline $\begin{array}{l}2016 \text { RIO Olympic Games } \\
\text { Sustainability Management } \\
\text { Plan }\end{array}$ & $\begin{array}{c}\text { Tokyo } 2020 \text { Olympic and Paralympic Games } \\
\text { High-Level Sustainability Plan }\end{array}$ \\
\hline $\begin{array}{l}\text { 1. Water treatment and } \\
\text { conservation } \\
\text { 2. Environmental awareness } \\
\text { 3. Use and management of } \\
\text { renewable energy } \\
\text { 4. Games neutral in carbon, air } \\
\text { quality and transport } \\
\text { 5. Protection of soils and } \\
\text { ecosystems } \\
\text { 6. Sustainable design and } \\
\text { construction } \\
\text { 7. Reforestation, biodiversity } \\
\text { and culture } \\
\text { 8. Shopping and ecological } \\
\text { certification } \\
\text { 9. Solid waste management }\end{array}$ & $\begin{array}{l}\text { 1. Climate Change (Low Carbon Management) } \\
\text { 2. Resource Management } \\
\text { 3. Natural Environment and Biodiversity } \\
\text { 4. Consideration of Human Rights, Labour and Fair } \\
\text { 5. Operating Practices } \\
\text { 6. Involvement, Cooperation and Communications } \\
\text { (Engagement) } \\
\text { 7. Tools for Realisation of the Plan } \\
\text { and includes (The Tokyo Organizing Committee of the } \\
\text { Olympic and Paralympic Games, 2016): } \\
\text { - Promotion and education of the importance of } \\
\text { sustainability; } \\
\text { - Measures aimed at enhancing understanding and sharing } \\
\text { of the importance of sustainability among staff, } \\
\text { volunteers, related corporate entities, athletes, spectators, } \\
\text { citizens, etc. through the Tokyo } 2020 \text { Games; } \\
\text { - Measures for taking sustainable actions and contribution } \\
\text { to the realization of a sustainable society. }\end{array}$ \\
\hline
\end{tabular}

Realization of Olympic Games involves a complex process of construction of real estate objects. Sustainable construction principles are also of high importance for a sustainable real estate market development. For example, sustainable construction as implemented in the UK (Cabinet Office and Infrastructure and Projects Authority of UK, 2016) are defined as follows, "Sustainable Construction is a Government initiated policy imperative to improve the social, economic and environmental performance of the UK construction industry" (Roy Stewart, n.d., retrieved 2017). 
Sustainable construction can be defined also in the following way (Kalnciems, n. d.):

- construction, the purpose of which is to significantly reduce the impact of the construction and operation of the building on the environment during its life cycle, and to ensure the economic benefit of the building construction, as well as the comfort and safety for the residents of this building;

- export-capable construction industry that can achieve long-term growth by efficiently solving the current problems of the wide range of the customers, while planning also the future developments.

Another important definition that should be considered analyzing the topic is the definition of Real Estate Market Management System, "The Real Estate Market Development Management System determines the theoretical basis and management of practical operation processes in real estate transactions at all levels of the hierarchy, developing a set of principles, methods, infrastructures, forms and organizations, tools for real estate management, business processes and development of business activity scenarios" (Geipele, 2015, p. 49).

On the basis of the previous research (Kauškale, Geipele, 2017 Kauškale, Geipele, Riemenschneider, 2016), and taking into account previously mentioned information, the authors offer two definitions of sustainable real estate market development:

1. Sustainable Real Estate Market Development is such a development that includes economic, social, environmental, political, technological and legal aspects of real estate market development, long-term national and real estate market development policies, conservation and preservation of the environment, housing affordability issues and development, which contribute to the quality of life of society during the entire real estate market cycle period.

2. Sustainable development of real estate market is a stable and balanced development of real estate market that meets the present needs of real estate market participants without compromising the ability of future generations to meet their own needs, realized by all market participants and at all levels.

The second definition is based on the definition of sustainable development concept provided in Brudtland Report (Our Common Future) (World Commission on Environment and Development, 1987). Sustainability participants by levels, activities, regulations and key participants in Latvia are shown in Table 2. 
Table 2. Main sustainable real estate market development influencing regulations and key participants by levels in Latvia [developed by authors]

\begin{tabular}{|c|c|c|}
\hline & Market participants & $\begin{array}{l}\text { Laws, regulations and documents influencing } \\
\text { sustainable real estate market development }\end{array}$ \\
\hline 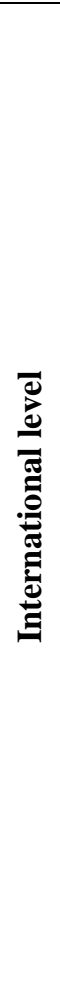 & $\begin{array}{c}\text { Government of the country, } \\
\text { International organizations and } \\
\text { unions, } \\
\text { European Parliament, } \\
\text { European Environmental } \\
\text { Bureau, } \\
\text { International real estate } \\
\text { organizations - e.g. FIABCI }\end{array}$ & $\begin{array}{l}\text { 2030, } 2050 \text { Sustainable Development Goals } \\
\text { Regulations, directives; } \\
\text { The Rio Declaration on Environment and Development; } \\
\text { UNEP, Principles of Sustainable Development, 2002; } \\
\text { Lisbon Strategy; } \\
\text { EUROPE } 2020 \text { strategy; } \\
\text { Commission strategy aiming to achieve a new } \\
\text { sustainable and greener economy; } \\
\text { Europe } 2050 \text { energy strategy The Ten Principles of the } \\
\text { UN Global Compact (Human Rights, Labour, } \\
\text { Environment, Anti-Corruption } \\
\text { Directive 2004/18/EC of the European Parliament and of } \\
\text { the Council on the coordination of procedures for the } \\
\text { award of public works contracts, public supply contracts } \\
\text { and public service contracts**; } \\
\text { Directive 2004/17/EC of the European Parliament and of } \\
\text { the Council coordinating the procurement procedures of } \\
\text { entities operating in the water, energy, transport and } \\
\text { postal services sectors**; } \\
\text { Directive 2014/24/EU and Directive } 2014 / 25 / \text { EU and } \\
\text { other documents and regulations** }\end{array}$ \\
\hline 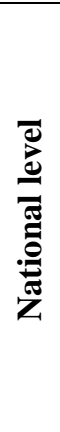 & $\begin{array}{c}\text { Government, Parliament, } \\
\text { Government institutions } \\
\text { In Latvia: Saeima (Landbook } \\
\text { Privatization Bureau, SJSC } \\
\text { "State Real Estate", "Latvia's } \\
\text { State Forests", } \\
\text { government and privatization } \\
\text { agencies }\end{array}$ & $\begin{array}{l}\text { Regulations, directives, laws: } \\
\text { Competition Law; } \\
\text { Immigration Law; } \\
\text { National Development Plan of Latvia for } 2014 \text { to } 2020 \text {; } \\
\text { National Industrial Policy Guidelines for } 2014 \text { to } 2020 \text {; } \\
\text { Latvian Convergence Programme for the year } 2013 \text { to } \\
2016 \text {; } \\
\text { Latvian Stability Programme for } 2014 \text { to } 2017 \text {; } \\
\text { Latvian long-term Energy Strategy } 2030 \text {, etc. }\end{array}$ \\
\hline 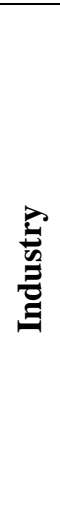 & $\begin{array}{l}\text { Organizations such as } \\
\text { LANĪDA, municipalities and } \\
\text { their owned real estate objects; } \\
\text { Latvian House Manager Guild; } \\
\text { Latvian House Manager and } \\
\text { Maintenance Provider } \\
\text { Association; } \\
\text { Association of Property } \\
\text { Appraisers in Latvia }\end{array}$ & $\begin{array}{l}\text { Unions, competition law and other industry regulation } \\
\text { influencing laws and regulations: } \\
\text { Public Procurement Law of Latvia and green public } \\
\text { procurement regulations and aspects; } \\
\text { Construction Law of Latvia; } \\
\text { the regulations of the Cabinet of Ministers, quality } \\
\text { standards and other regulations and documents }\end{array}$ \\
\hline
\end{tabular}




\begin{tabular}{|c|c|c|}
\hline 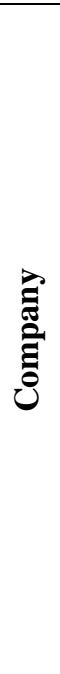 & $\begin{array}{l}\text { Owners, managers, employees, } \\
\text { builders, investors, developers, } \\
\text { brokers, banks, bank } \\
\text { subsidiaries, acquisition } \\
\text { officers, analysts, portfolio } \\
\text { managers, asset managers, } \\
\text { property managers, finance } \\
\text { and accounting, } \\
\text { administrators, procurists, } \\
\text { environmental consultants, } \\
\text { architects, surveyors, planning } \\
\text { and zoning specialists, brokers, } \\
\text { investment specialists, lawyers } \\
\text { in field of real estate, notaries * }\end{array}$ & $\begin{array}{l}\text { Corporate social responsibility aspects } \\
\text { Integration of ESG criteria in management } \\
\text { Construction Law } \\
\text { Environmental Law } \\
\text { ISO standards and other documents and regulations }\end{array}$ \\
\hline $\begin{array}{l}\frac{n}{0} \\
\frac{0}{2} \\
\frac{1}{0} \\
0 \\
0 \\
0\end{array}$ & Real estate buyers and sellers & $\begin{array}{l}\text { Activities on real estate market; } \\
\text { Buying/selling/renting real estate; } \\
\text { Housing maintenance }\end{array}$ \\
\hline 尝 & $\begin{array}{c}\text { Real estate buyers and sellers } \\
\text { living behaviour }\end{array}$ & $\begin{array}{l}\text { Individual decision making areas; } \\
\text { Buying/selling/renting real estate analysis and activities; } \\
\text { Housing maintenance }\end{array}$ \\
\hline
\end{tabular}

Construction process in the country is strongly connected with the amount of investment in the industry. For sustainability assessment it is important to define the amount of investment into environment and ecological buildings.

Environmental aspects of construction are integrated also in the Public Procurement Law (2017), where the green public procurement is defined. Green public procurement is a purchase of goods, services and works whose environmental impact during their life cycle is lower than those of the goods, services and works of the same usage objective that were purchased without applying the principles of green public procurement (Public Procurement Law, 2017). Green public procurement aims, EU directives and regulations in Latvia are summarized in Table 3. 
Table 3. Green public procurement aims, EU directives and regulations in Latvia (The Ministry of Environmental Protection and Regional Development, 2017) [developed by authors]

\begin{tabular}{|c|c|}
\hline Parameter & Description \\
\hline Goals & $\begin{array}{l}\text { The Government Action Plan } 2014 \text { stipulates that one of the } \\
\text { Government's goals is to develop and implement the principle of "green } \\
\text { procurement" (GP) in public and public procurement, promoting the growth } \\
\text { of healthy food and local materials (including wood). The goal of the "Green } \\
\text { Procurement Plan for } 2015-2017 \text { " is to increase the volume of purchased } \\
\text { goods and services at the end of } 2015 \text { by at least } 15 \% \text { in financial terms } \\
\text { from the total purchases of state and local government institutions, in } 2016- \\
\text { by } 20 \% \text { and in } 2017 \text { - by } 30 \% \text {. }\end{array}$ \\
\hline $\begin{array}{l}\text { European Union } \\
\text { Directives }\end{array}$ & $\begin{array}{l}\text { In the EU Member States, the procurement framework since } 2004 \\
\text { consists of two public procurement directives which provide for the inclusion } \\
\text { of environmental conditions in procurement procedures if the procurement } \\
\text { exceeds a certain threshold: } \\
\text { Directive } 2004 / 18 / \mathrm{EC} \text { of the European Parliament and of the Council on } \\
\text { the coordination of procedures for the award of public works contracts, } \\
\text { public supply contracts and public service contracts; } \\
\text { Directive } 2004 / 17 / \mathrm{EC} \text { of the European Parliament and of the Council } \\
\text { coordinating the procurement procedures of entities operating in the water, } \\
\text { energy, transport and postal services sectors. } \\
\text { On February } 26,2014 \text {, Directive } 2014 / 24 / \text { EU and Directive } 2014 / 25 / E U \text {, } \\
\text { envisaging the inclusion of environmental criteria in public procurement, } \\
\text { which are to be transposed into national law by April } 18,2016 \text {, were } \\
\text { adopted. }\end{array}$ \\
\hline $\begin{array}{l}\text { Regulations in } \\
\text { Latvia }\end{array}$ & $\begin{array}{l}\text { The Ministry of Environmental Protection and Regional Development, } \\
\text { in co-operation with stakeholders, elaborated the "Green Procurement } \\
\text { Promotion Plan for 2015-2017", (approved by the Cabinet of Ministers on } \\
\text { February 17, 2015). The Green Procurement Plan describes the current } \\
\text { situation, including identifying key issues related to the implementation of } \\
\text { the ZERA and ZI, and includes concrete steps to address these issues. } \\
\text { The requirements of EU Directives have been incorporated into the } \\
\text { national law of the Member States. In Latvia, this is determined by the Public } \\
\text { Procurement Law and the Law "On Procurement for the Needs of Public } \\
\text { Service Providers". }\end{array}$ \\
\hline
\end{tabular}

Construction process is directly influenced by land management issues and regulations. "Land Management is the set of measures of the land policy implementation, the objective of which is to promote the sustainable land use and protection" (Legislation of the Republic of Latvia, Land Management Law, 2014). Evaluation Methodology of Land Use Efficiency in Land Management was analyzed by Armands Auziņš (2013) and the Sustainable Land Management Systems framework model was developed (Auziņš, Grinbergs, Geipele, 2012). Environmental issues are also relevant in terms of land use efficiency. "Land use efficiency is an indicator that includes benefits from a single land unit over a certain period of time, using it for a specific purpose" (Auziņš, Grinbergs, Geipele, 2012, p. 31). Environmental, energy, pollution, resource and transport taxes (last available information) are shown in Table 4 and Table 5. 
Table 4. Environmental tax revenues in Latvia, MEuro. Data: Eurostat (n. d.) (last available data on September 10, 2017) [developed by authors]

\begin{tabular}{|c|c|c|c|c|c|c|c|}
\hline \multicolumn{8}{|c|}{ Environmental taxes } \\
\hline GEO/TIME & 2008 & 2009 & 2010 & 2011 & 2012 & 2013 & 2014 \\
\hline $\begin{array}{l}\text { Agriculture, } \\
\text { forestry and } \\
\text { fishing }\end{array}$ & 33.41 & 36.65 & 15.79 & 29.95 & 32.09 & 32.45 & 30.61 \\
\hline Construction & 28.53 & 18.76 & 17.60 & 20.78 & 24.66 & 20.67 & 22.18 \\
\hline $\begin{array}{l}\text { Rental and leasing } \\
\text { activities }\end{array}$ & 3.01 & 1.22 & 0.46 & 3.85 & 1.04 & 2.56 & 2.17 \\
\hline $\begin{array}{l}\text { Electricity, gas, } \\
\text { steam and air } \\
\text { conditioning supply }\end{array}$ & 2.06 & 1.91 & 1.47 & 2.69 & 1.99 & 2.12 & 2.42 \\
\hline $\begin{array}{l}\text { Real estate } \\
\text { activities }\end{array}$ & 2.47 & 2.27 & 1.80 & 3.45 & 2.64 & 2.91 & 3.33 \\
\hline \multicolumn{8}{|l|}{ Energy taxes } \\
\hline GEO/TIME & 2008 & 2009 & 2010 & 2011 & 2012 & 2013 & 2014 \\
\hline $\begin{array}{l}\text { Agriculture, } \\
\text { forestry and } \\
\text { fishing }\end{array}$ & 0.11 & 0.11 & 0.13 & 0.15 & 0.14 & 0.16 & 0.18 \\
\hline Construction & 0.16 & 0.15 & 0.18 & 0.06 & 0.10 & 0.07 & 0.06 \\
\hline $\begin{array}{l}\text { Rental and leasing } \\
\text { activities }\end{array}$ & 0.01 & 0.00 & 0.01 & 0.01 & 0.00 & 0.01 & 0.00 \\
\hline $\begin{array}{l}\text { Electricity, gas, } \\
\text { steam and air } \\
\text { conditioning } \\
\text { supply }\end{array}$ & 0.51 & 0.62 & 0.65 & 0.76 & 0.88 & 0.59 & 1.32 \\
\hline $\begin{array}{l}\text { Water supply; } \\
\text { sewerage, waste } \\
\text { management and } \\
\text { remediation } \\
\text { activities }\end{array}$ & 0.67 & 2.04 & 1.59 & 3.51 & 4.79 & 5.61 & 5.30 \\
\hline $\begin{array}{l}\text { Real estate } \\
\text { activities }\end{array}$ & 0.08 & 0.05 & 0.07 & 0.01 & 0.02 & 0.19 & 0.03 \\
\hline \multicolumn{8}{|l|}{ Pollution taxes } \\
\hline GEO/TIME & 2008 & 2009 & 2010 & 2011 & 2012 & 2013 & 2014 \\
\hline $\begin{array}{l}\text { Agriculture, } \\
\text { forestry and } \\
\text { fishing }\end{array}$ & 0.11 & 0.11 & 0.13 & 0.15 & 0.14 & 0.16 & 0.18 \\
\hline Construction & 0.16 & 0.15 & 0.18 & 0.06 & 0.10 & 0.07 & 0.06 \\
\hline $\begin{array}{l}\text { Rental and leasing } \\
\text { activities }\end{array}$ & 0.01 & 0.00 & 0.01 & 0.01 & 0.00 & 0.01 & 0.00 \\
\hline $\begin{array}{l}\text { Electricity, gas, } \\
\text { steam and air } \\
\text { conditioning } \\
\text { supply }\end{array}$ & 0.51 & 0.62 & 0.65 & 0.76 & 0.88 & 0.59 & 1.32 \\
\hline $\begin{array}{l}\text { Water supply; } \\
\text { sewerage, waste } \\
\text { management and } \\
\text { remediation } \\
\text { activities }\end{array}$ & 0.67 & 2.04 & 1.59 & 3.51 & 4.79 & 5.61 & 5.30 \\
\hline
\end{tabular}




\begin{tabular}{|c|c|c|c|c|c|c|c|}
\hline $\begin{array}{l}\text { Real estate } \\
\text { activities }\end{array}$ & 0.08 & 0.05 & 0.07 & 0.01 & 0.02 & 0.19 & 0.03 \\
\hline \multicolumn{8}{|l|}{ Resource taxes } \\
\hline GEO/TIME & 2008 & 2009 & 2010 & 2011 & 2012 & 2013 & 2014 \\
\hline $\begin{array}{l}\text { Agriculture, } \\
\text { forestry and } \\
\text { fishing }\end{array}$ & 0.70 & 0.64 & 0.65 & 0.75 & 0.79 & 0.82 & 0.88 \\
\hline Construction & 0.36 & 0.19 & 0.22 & 0.53 & 0.63 & 0.70 & 0.55 \\
\hline $\begin{array}{l}\text { Rental and leasing } \\
\text { activities }\end{array}$ & 0.00 & 0.00 & 0.00 & 0.00 & 0.02 & 0.02 & 0.03 \\
\hline $\begin{array}{l}\text { Electricity, gas, } \\
\text { steam and air } \\
\text { conditioning } \\
\text { supply }\end{array}$ & 0.29 & 0.24 & 0.21 & 0.45 & 0.51 & 1.05 & 0.72 \\
\hline $\begin{array}{l}\text { Water supply; } \\
\text { sewerage, waste } \\
\text { management and } \\
\text { remediation } \\
\text { activities }\end{array}$ & 2.33 & 0.98 & 1.31 & 2.17 & 2.47 & 1.61 & 2.47 \\
\hline $\begin{array}{l}\text { Real estate } \\
\text { activities }\end{array}$ & 0.11 & 0.11 & 0.09 & 0.21 & 0.26 & 0.20 & 0.44 \\
\hline \multicolumn{8}{|l|}{ Transport taxes } \\
\hline GEO/TIME & 2008 & 2009 & 2010 & 2011 & 2012 & 2013 & 2014 \\
\hline $\begin{array}{l}\text { Agriculture, } \\
\text { forestry and } \\
\text { fishing }\end{array}$ & 1.22 & 1.04 & 1.33 & 3.73 & 3.93 & 3.39 & 2.92 \\
\hline Construction & 3.38 & 1.93 & 1.93 & 3.84 & 4.45 & 4.35 & 4.67 \\
\hline $\begin{array}{l}\text { Rental and } \\
\text { leasing activities }\end{array}$ & 0.35 & 0.14 & 0.06 & 1.19 & 0.30 & 0.63 & 0.70 \\
\hline $\begin{array}{l}\text { Electricity, gas, } \\
\text { steam and air } \\
\text { conditioning } \\
\text { supply }\end{array}$ & 0.27 & 0.21 & 0.19 & 0.40 & 0.40 & 0.47 & 0.51 \\
\hline $\begin{array}{l}\text { Water supply; } \\
\text { sewerage, waste } \\
\text { management and } \\
\text { remediation } \\
\text { activities }\end{array}$ & 0.37 & 0.37 & 0.30 & 1.29 & 0.77 & 0.49 & 0.81 \\
\hline $\begin{array}{l}\text { Real estate } \\
\text { activities }\end{array}$ & 0.22 & 0.20 & 0.18 & 0.55 & 0.37 & 0.40 & 0.44 \\
\hline
\end{tabular}

Table 5. Environmental tax revenues in the Baltic States, total, M Euro. Data: Eurostat (n. d.) (last available data on October 17, 2017) [developed by authors]

\begin{tabular}{|l|c|c|c|c|c|c|c|c|c|c|c|c|}
\hline GEO/TIME & 2004 & 2005 & 2006 & 2007 & 2008 & 2009 & 2010 & 2011 & 2012 & 2013 & 2014 & 2015 \\
\hline Estonia & 203.87 & 255.72 & 295.95 & 355.68 & 382.46 & 415.93 & 431.60 & 454.26 & 489.06 & 484.64 & 533.05 & 557.82 \\
\hline Latvia & 287.45 & 346.45 & 385.25 & 437.21 & 449.44 & 431.90 & 432.80 & 497.60 & 537.61 & 558.21 & 630.13 & 658.93 \\
\hline Lithuania & 491.98 & 481.52 & 433.42 & 507.56 & 533.52 & 542.78 & 512.22 & 527.68 & 548.13 & 572.34 & 618.95 & 676.88 \\
\hline
\end{tabular}


Growth of the environmental tax revenues may be a result of increase of the environment non-friendly activities. After analysis of the international experience, in the next part the authors analyze the latest tendencies of green building development in Latvia.

\section{THE LATEST TENDENCIES OF GREEN BUILDING DEVELOPMENT IN LATVIA}

Environmental aspects are integrated in the Construction Law. The purpose of the Construction Law of Latvia (2014) is to create a quality living environment by establishing an effective regulation of the construction process in order to ensure sustainable economic and social development of the country, preservation of cultural and historical values and environmental values, as well as rational use of energy resources. Construction quality and safety in Latvia has been ensured by State Construction Control Bureau of Latvia from October 1, 2014 (The State Construction Control Bureau of Latvia, 2017).

The European Parliament and the Council of European Union developed Regulation (EU) No 305/2011 of the European Parliament and of the Council of 9 March 2011 that laid down the harmonized conditions for the marketing of construction products and repealing Council Directive 89/106/EEC (The European Parliament and the Council of European Union, 2011). Latvian Sustainable Building Council (LSBC), NGO, was founded in 2010 as a private sector initiative with an aim to increase the sustainability of the built environment in Latvia. 2012 LSBC joined the World Green Building Council (WGBC) - an international network of more than 90 local organizations with similar main aims in 5 continents (Latvian Sustainable Building Council, n. d.).

All above-mentioned aspects influence the construction industry, as well as real estate market development. However, the sustainability concept of real estate market development is a more complex system as sustainable construction aspects are just one part of them.

The Declaration on the Improvement of the Long-Term Strategy for the Modernization of the Latvian Buildings 2014-2020, developed within the framework of the BUILD UPON project of the EU research program "Horizons2020" has been approved (Latvian Sustainable Building Council, 2017), and the catalog on products, services and construction in the framework of Green Public Procurement has been developed, where the following groups have been created in the directory:

- Office building design, construction and management;

- Road design, construction and maintenance;

- Transport;

- Indoor lighting;

- Street lighting and traffic signals;

- Image equipment;

- Office IT equipment;

- Energy efficiency services;

- Solar collectors; 
- Solar cells.

The winners in the nomination "The Most Sustainable Building in Latvia in 2016" are listed below. The buildings which have been put into operation at least a year ago and have passed at least one heating season can compete in this nomination. (Construction of Latvia, 2016):

- $\quad 1^{\text {st }}$ place - reconstruction of Lūznava Manor, contractor Rezekne District Municipality, project "Ināras Caunītes arhitektu birojs", constructor "R.A.J.";

- $\quad 2^{\text {nd }}$ place - Jurmala Art School, contractor Jurmala Municipality, project "Skonto Būve";

- $3^{\text {rd }}$ place - Creative Center "Zeimuls", contractor Rezekne Municipality, project "SAALS", constructor "RE \& RE".

Currently in Latvia, BREEAM is the most popular international green building certification system, BREEAM certified real estate object can be found in Table 6.

Table 6. BREEAM certified projects in Latvia on August 31, 2017

(BRE Group, n. d.)

\begin{tabular}{|c|c|c|c|c|c|c|c|c|}
\hline Building & Client & \multirow{3}{*}{ Scheme } & Rating & Stage & \multirow{3}{*}{ Cert. No. } & Assessor & Town & \multirow{3}{*}{ Country } \\
\hline \multirow[t]{2}{*}{ Asset Name } & Developer & & Score & Valid Until & & Auditor & Postcode & \\
\hline & & & & & & & Zip code & \\
\hline \multirow{2}{*}{$\begin{array}{l}\text { Business } \\
\text { Center PLACE } \\
\text { ELEVEN }\end{array}$} & \multirow[t]{2}{*}{ TBA } & \multirow{2}{*}{$\begin{array}{l}\text { International } \\
\text { 2013 New } \\
\text { Construction: } \\
\text { Offices }\end{array}$} & Excellent & \multirow[t]{2}{*}{ Interim } & \multirow[t]{2}{*}{$\begin{array}{l}\text { BREEAM- } \\
\text { 0056-5259 }\end{array}$} & \multirow[t]{2}{*}{$\begin{array}{l}\text { UAB Vesta } \\
\text { Consulting }\end{array}$} & Riga & \multirow[t]{2}{*}{ Latvia } \\
\hline & & & $72.40 \%$ & & & & LV-1013 & \\
\hline \multirow{2}{*}{$\begin{array}{l}\text { Business } \\
\text { Center PLACE } \\
\text { ELEVEN }\end{array}$} & \multirow[t]{2}{*}{$\begin{array}{l}\text { Hanner } \\
\text { Group }\end{array}$} & \multirow{2}{*}{$\begin{array}{l}\text { International } \\
\text { 2013 New } \\
\text { Construction: } \\
\text { Offices }\end{array}$} & Excellent & \multirow[t]{2}{*}{ Final } & \multirow[t]{2}{*}{$\begin{array}{l}\text { BREEAM- } \\
0069-5171\end{array}$} & \multirow[t]{2}{*}{$\begin{array}{l}\text { UAB Vesta } \\
\text { Consulting }\end{array}$} & Riga & \multirow[t]{2}{*}{ Latvia } \\
\hline & & & $74.30 \%$ & & & & LV-1013 & \\
\hline \multirow[t]{2}{*}{ FeliCity } & \multirow[t]{2}{*}{ Nare Ltd } & \multirow[t]{2}{*}{$\begin{array}{l}\text { International } \\
\text { 2013 New } \\
\text { Construction: } \\
\text { Residential }\end{array}$} & Pass & \multirow[t]{2}{*}{ Interim } & \multirow[t]{2}{*}{$\begin{array}{l}\text { BREEAM- } \\
\text { 0051-5239 }\end{array}$} & \multirow[t]{2}{*}{$\begin{array}{l}\text { IB\&P } \\
\text { Konsultacija } \\
\text { s }\end{array}$} & Riga & \multirow[t]{2}{*}{ Latvia } \\
\hline & & & $35.40 \%$ & & & & LV-1010 & \\
\hline \multirow[t]{2}{*}{$\begin{array}{l}\text { FeliCity } \\
\text { Apartments }\end{array}$} & \multirow[t]{2}{*}{ Nāre, Ltd } & \multirow[t]{2}{*}{$\begin{array}{l}\text { International } \\
\text { 2013 New } \\
\text { Construction: } \\
\text { Residential }\end{array}$} & Pass & \multirow[t]{2}{*}{ Final } & \multirow[t]{2}{*}{$\begin{array}{l}\text { BREEAM- } \\
0062-2555\end{array}$} & \multirow[t]{2}{*}{$\begin{array}{l}\text { IB\&P } \\
\text { Konsultacija } \\
\mathrm{s}\end{array}$} & Riga & \multirow[t]{2}{*}{ Latvia } \\
\hline & & & $36.50 \%$ & & & & LV-1011 & \\
\hline
\end{tabular}




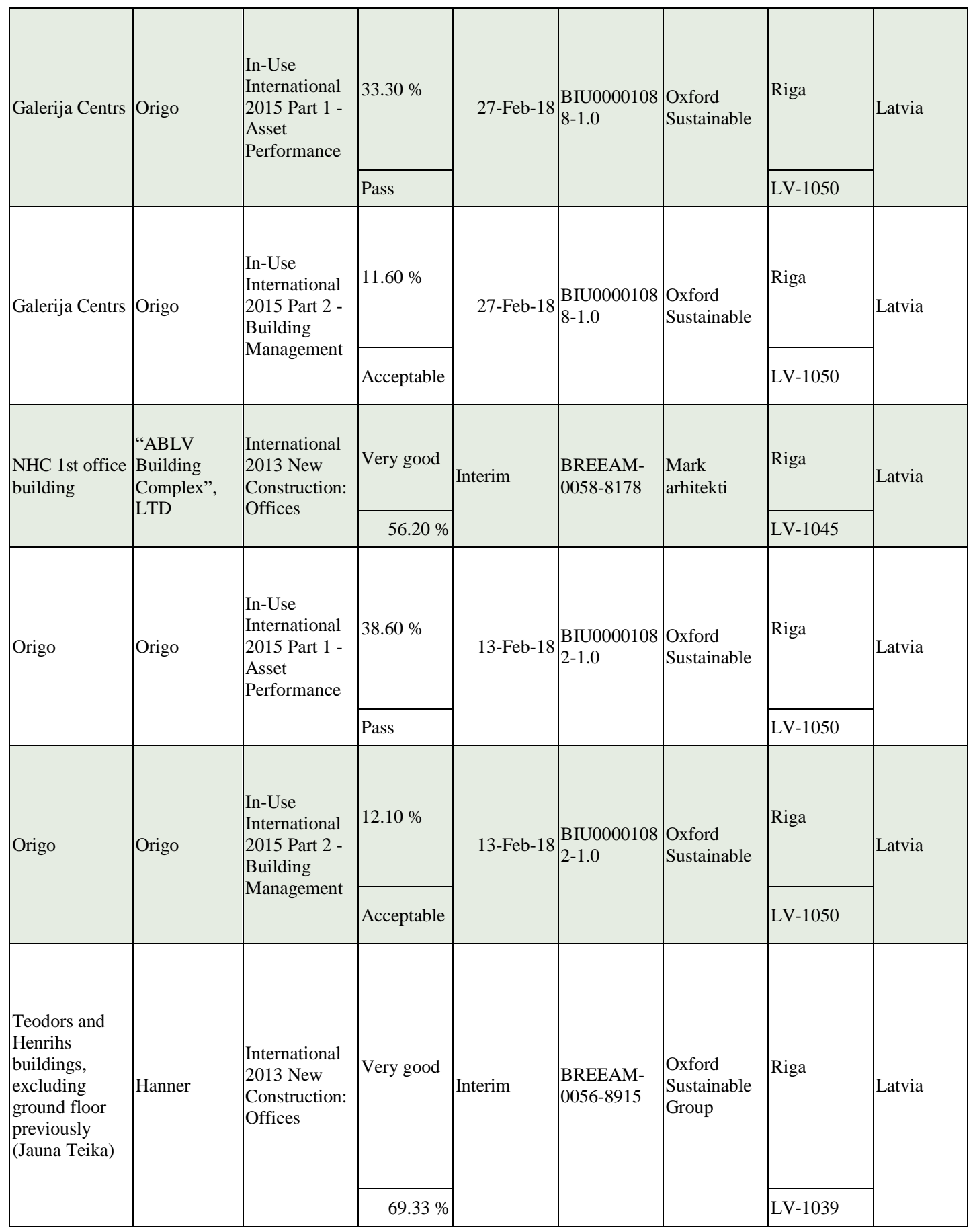

There is also one LEED certified project on Zala 1, Office Building in Riga, Latvia by Vastint Latvia Office / $58716 \mathrm{ft}^{2}$, and one for LEED certification registered object - SIA Krasta SP Office / $699654 \mathrm{ft}^{2}$, in Riga (Green Building Information Gateway, n. d.).

The Camphill village communities are considered to be the pioneer of ecovillages in Western Europe; these communities began to emerge in the 1930s and 1940s, and currently there are around 100 Camphill ecovillages around the 
world (Ekociemati.lv, 2016a). Ecovillage is a small community of people where their needs are closely related to nature and the natural environment; the people in ecovillages live ecologically and economically in order to ensure longer life for themselves and the whole world (Ekociemati.lv, 2016b). The ecovillage movement appeared in Latvia in 1999 when the Neimanu family began to form a small village of Camphill in its ownership in the Rencenu Parish, Valmiera, based on the anthroposophy knowledge obtained in Norway (Polis, 2010).

Governmental expenditure for environmental protection is of great importance for environmental development. Investments and current expenditure tendencies and the structure for environmental protection by environmental area in Latvia from year 2006 to 2015 are shown in Figure 1.

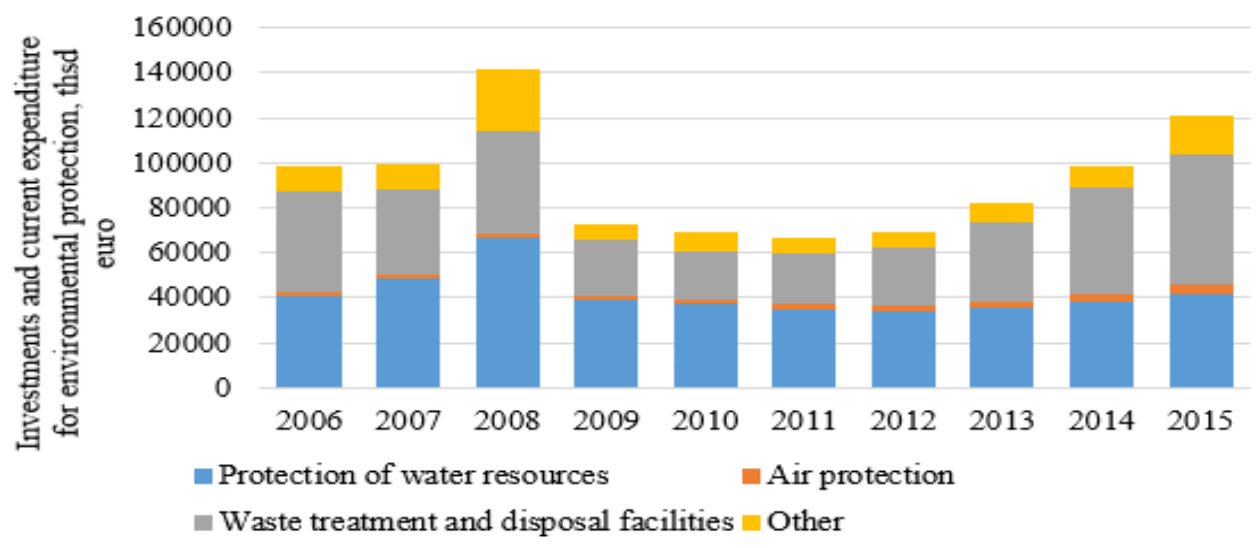

Fig. 1. Investments and current expenditure for environmental protection by environmental area in Latvia (thsd euro excluding VAT) Data: Central Statistical Bureau of Latvia (2017). [Figure developed by authors].

The chart on investments and current expenditure for environmental protection by environmental area in Latvia shows that the volumes of investments and expenditure for environmental protection are increasing from year 2011, but still have not reached the level of year 2008. Environmental taxes in Latvia were analyzed in Table 6.

Expectations of developers and construction confidence indicators are of special importance for construction industry development. Construction confidence indicators in the Baltic States, seasonally adjusted data, not calendar adjusted data, are shown at Figure 2. 


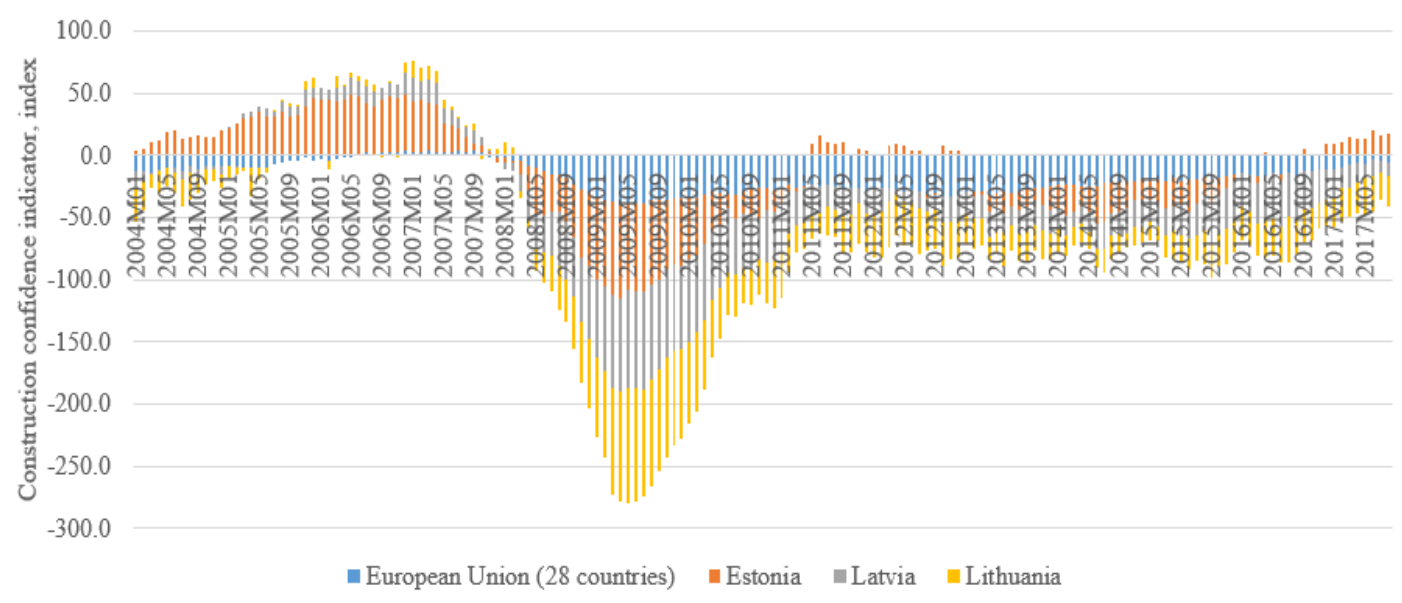

Fig. 2. Construction confidence indicators in the Baltic States, seasonally adjusted data, not calendar adjusted data. Data: Eurostat (n. d.). [Figure developed by authors].

Figure 2 demonstrates the cyclical development of construction confidence indicators in the Baltic States and importance of seasonal aspects in construction process. Currently, the positive construction confidence indicators in the Baltic States can be observed, that is a positive tendency also for green building development opportunities.

\section{CONCLUSION}

The article investigates the environmental aspects of construction industry development, with particular focus on the case of Latvia, it analyzes the main sustainable real estate market development influencing laws, regulations and documents by levels in Latvia, defines the concept of sustainable real estate market development.

- The results of the research show positive green construction development tendencies in Latvia, however, the number of green buildings in Latvia is lower in comparison with global experience, which impedes achievement of greenhouse gas emission reduction targets and other possible environmental improvements.

- Compliance with environmental and sustainability requirements in buildings includes a number of activities and regulations, and the observance of the above-mentioned documents and the use of opportunities is important for a sustainable development of cities and the country;

- The results of the research show that compliance with environmental requirements in construction is a necessity for market participants and industry development, and green buildings and construction is a future need as well, so gradual transition to green construction is necessary.

Construction confidence indicators can directly influence construction industry development tendencies, as well as green building development, so there 
is an interconnection with green building development. The future research direction may be the analysis of practical implementation of green building and sustainability strategies at construction companies by developers and in real estate operation enterprises. Results of the research have shown that there is a high necessity for green building construction from different points of view.

\section{REFERENCES}

Actiņa, G., Geipele, I., \& Zeltiņš, N. (2015). Planning and Managing Problems of Energy and Energy Efficiency at Regional and District Level in Latvia: Case study. In International Conference on Industrial Engineering and Operations Management (IEOM) (pp. 1-7). https://doi.org/10.1109/IEOM.2015.7093843

Auziņš, A., Grinbergs, M., \& Geipele, I. (2012). Influence of Development of Land Use Goals to the Economics of Latvia. In 2nd International Conference on Applied Social Science (ICASS 2012), (pp. 238-243). Malaysia, Kuala Lumpur, 1-2 February, 2012. Los Angeles: Information Engineering Research Institute, 2012. ISBN 9781612750064

BRE Group. (n. d.). Certified BREEAM Assessments. Retrieved from http://www.greenbooklive.com/search/scheme.jsp?id=202

Cabinet Office and Infrastructure and Projects Authority of UK. (2016, March 23). Government Construction Strategy: 2016-2020. Retrieved from https://www.gov.uk/government/publications/government-construction-strategy-2016-2020

Central Statistical Bureau of Latvia. (2017, Oct. 18). Statistic database. Retrieved from http://www.csb.gov.lv/dati/statistikas-datubazes-28270.html

Construction Law [Būvniecības likums]. (2014). Adopted on 07.09.2013. Effective: 01.10.2014. Published in "Latvian Herald", 146 (4952), 30.07.2013. Retrieved from https://likumi.lv/doc.php?id=258572

Ekociemati.lv (2016a). Ekociemati Latvijā un pasaulē [Eco villages in Latvia and worldwide]. (2017). Retrieved from http://ekociemati.lv/

Ekociemati.lv (2016b). Kas ir ekociemati? [What are ecovillage?] (2016). Retrieved from http://ekociemati.lv/2016/11/24/kas-ir-ekociemati/

Eurostat. (n. d.) European statistics database. Retrieved from http://ec.europa.eu/eurostat/data/database

Geipele, S. (2015). Management System of Real Estate Market Development in Latvia. Riga: RTU Press. ISBN 978-9934-10-761-0. https://doi.org/10.7250/9789934107610

Green Building Information Gateway (GBIG). (n. d.). Latvia. Retrieved from http://www.gbig.org/places/697/activities?page=1

Kalnciems, K. (n. d.). Zaḷā ekonomika un ilgtspējīgāas būvniecības uzplaukums [Green economy and the flourishing of sustainable construction]. Retrieved from: http://www.tb.lv/tl_files/lejupieladei/dazhadi/Zala-ekonomika2012/6_KK_ZE_Ilgtspejiga_buvnieciba_12_10_01.pdf

Kauškale, L., \& Geipele, I. (2017). Integrated Approach of Real Estate Market Analysis in Sustainable Development Context for Decision Making. Procedia Engineering, 172, 505-512. ISSN 1877-7058. https://doi.org/10.1016/j.proeng.2017.02.059

Kauškale, L., \& Riemenschneider, F. (2016). The Environmental and Economic Substantiation of Investments in Green Buildings. Baltic Journal of Real Estate Economics and Construction Management, 4, 126-144. ISSN 2255-9604. e-ISSN 2255-9671. https://doi.org/10.1515/bjreecm-2016-0010

Kauškale, L., Geipele, I., \& Riemenschneider, F. (2016). Contemporary Sustainable Development Problems of Construction Industry: Case of Latvia. In Proceedings of Research World International Conference (pp. 5-11). Singapore, 4 March, 2016. Khandagiri, Bhubaneswar. ISBN 978-93-85973-55-0.

Kauškale, L., Geipele, I., Zeltiņš, N., \& Lecis, I. (2016). Energy Aspects of Green Buildings International Experience. Latvian Journal of Physics and Technical Sciences, 6, 21-28. ISSN 0868-8257. https://doi.org/10.1515/lpts-2016-0040 
Kauškale, L., Geipele, I., Zeltiňš, N., \& Lecis, I. (2017). Environmental and Energy Aspects of Construction Industry and Green Buildings. Latvian Journal of Physics and Technical Sciences, 54(2), 24-33. ISSN 0868-8257. https://doi.org/10.1515/lpts-2017-0010

Latvian Sustainable Building Council. (n. d.). Latvian Sustainable Building Council. Retrieved from http://www.ibp.lv/en

Latvian Sustainable Building Council. (2017, Feb. 19). Apstiprināta LIBP izstrādāta deklarācija Latvijas Ēku renovācijas ilgtermiņa stratēǵijas 2014. - 2020. gadam pilnveidošanu [Approved LIBP Declaration for Improvement of the Long-Term Strategy for the Modernization of Latvian Buildings 2014-2020]. Retrieved from http://www.ibp.lv/lv/jaunumi/build-upon-noslegumapasakums-17februari

Latvijas Būvniecība [Construction of Latvia]. (2016). Konkursa Ilgtspējīgākā ēka un projekts 2016 rezultāti [The Contest's Sustainable Building and Project 2016 Results]. Retrieved from http://www.latvijasbuvnieciba.lv/LB/ilgstspejiba-2016/

Mattoni, B., Guattari, C., Evangelisti, L., Bisegna, F., Gori, P., \& Asdrubali, F. (2018). Critical Review and Methodological Approach to Evaluate the Differences Among International Green Building Rating Tools. Renewable and Sustainable Energy Reviews, 82, 950-960. ISSN 13640321. https://doi.org/10.1016/j.rser.2017.09.105

Olympic games. (n. d.). The Organisation. 2016 Olympic games sustainability management plan. Retrieved from https://www.rio2016.com/transparencia/sites/default/files/sustainability_ management_plan_aug2013.pdf

Polis, A. (2010, April 3). Ekociemati Latvijā [Ecovillages in Latvia]. Vides Vēstis, Zaḷā dzīvesveida stila žurnāls [Green Lifestyle Style Magazine]. Retrieved from http://www.videsvestis.lv/ekociemati-latvija/

Publisko iepirkumu likums [Public Procurement Law] Published by Latvian Herald. 254 (5826), 29.12.2016. Accepted: 15.12.2016. Effective: 01/03/2017. Retrieved from https://likumi.lv/ta/id/287760-publisko-iepirkumu-likums

Reed, R. G., Krajinovic-Bilos, A., \& Reed, M. A. J. (2017). Green Building Rating Systems. In Martin A. Abraham (Ed.), Encyclopedia of Sustainable Technologies (pp. 99-112), Elsevier, Oxford. ISBN 9780128047927, https://doi.org/10.1016/B978-0-12-409548-9.10187-3

Roy Stewart. (n. d.). An Introduction to Sustainable Construction and the Environment. Retrieved from http://www.ccinw.com/images/publications/Workshop_5.pdf

Šnīdere, L., Geipele, I., \& Stāmure, I. (2017). Case Study of Standard Multi-Storey Residential Building Owners and Tenants' Perception of Building Technical Conditions and Renovation Issues. Baltic Journal of Real Estate Economics and Construction Management, 3, 6-22. e-ISSN 2255-9671. https://doi.org/10.1515/bjreecm-2017-0002

Stāmure, I., Kamola, L., \& Geipele, I. (2015). Practical Aspects of Sustainable Construction in Latvia. In 5th International Conference on Industrial Engineering and Operations Management, United Arab Emirates, Dubai, 3-5 March 2015. Dubai: IEOM Society, pp. 2041-2048. ISBN 978-0-9855497-2-5. e-ISBN 978-0-9855497-2-5. ISSN 2169-8767. e-ISSN 2169-8767. https://doi.org/10.1109/IEOM.2015.7093926

Tam, V. W. Y., Karimipour, H., Le, K. N., \& Wang, J. (2018). Green Neighbourhood: Review on the International Assessment Systems. Renewable and Sustainable Energy Reviews. 82, 689-699. https://doi.org/10.1016/j.rser.2017.09.083

Tambovceva, T., Geipele, I., \& Geipele, S. (2011). Green Building Assessment System Development in Latvia. In Proceedings of the 7th International Conference Management of Technological Changes (MTC 2011) (pp. 141-145). Greece, Alexandroupoli, 1-3 September 2011. Alexandroupolis: Democritus University of Thrace. ISBN 9789609948616. Acception number: WOS:000306940000036

The European Parliament and the Council of European Union. (2011). Regulation (EU) No 305/2011 of The European Parliament and the Council of European Union of 9 March 2011 laying down harmonised conditions for the marketing of construction products and repealing Council Directive 89/106/EEC. Official Journal of European Union, L 88/5. Retrieved from http://bvkb.gov.lv/sites/default/files/cpr_no_305_2011.pdf 
The Ministry of Environmental Protection and Regional Development. (n. d.). Green public procurement. Retrieved from http://www.varam.gov.lv/lat/darbibas_veidi/zalais_publiskais_iepirkums/

The State Construction Control Bureau of Latvia [Būvniecības valsts kontroles birojs]. (n. d.). About us. Retrieved from http://bvkb.gov.lv/en/content/about-us

The Tokyo Organising Committee of the Olympic and Paralympic Games. (2016). Tokyo 2020 Olympic and Paralympic Games High-level Sustainability Plan https://tokyo2020.jp/en/games/sustainability/data/sus-plan-EN.pdf

UNEP (United Nations Environment Programme). (2012). Geo5 Global Environmental Outlook. Environment for the future we want. Malta: Progress Press Ltd. Retrieved from http://www.unep.org/geo/sites/unep.org.geo/files/documents/geo5_report_c11.pdf

World Commission on Environment and Development. (1987). Our Common Future (Brudtland Report). Retrieved from http://www.un-documents.net/our-common-future.pdf

\section{AUTHORS' SHORT BIOGRAPHIES}

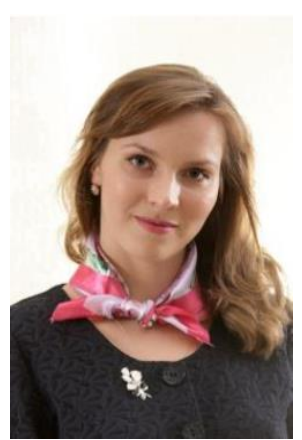

Linda Kauškale, $\mathrm{Mg}$. oec., is a lecturer, a $\mathrm{PhD}$ student and an assistant researcher of the Institute of Civil Engineering and Real Estate Economics, Faculty of Engineering Economics and Management, Riga Technical University. She with distinction obtained Professional Master Degree in Civil Construction and Real Estate Management, has the qualification of Real Estate Economist and extensive practical experience.

She has participated in international scientific conferences and seminars in Latvia, Germany, United Arab Emirates, Singapore, Malaysia, Lithuania etc. Her main research areas are sustainable real estate market concept, sustainable cities and sustainable construction, green buildings, macroeconomic analysis, business cycle, decision-making, environmental development problems, etc. She is DGNB (Deutsche Gesellschaft für nachhaltiges Bauen German Sustainable Building Council) Registered Professional. In year 2016 she was a Professional Member of Industrial Engineering and Operations Management Society. In autumn 2016, she was Deutsche Bundesstiftung Umwelt (German Environmental Foundation) Scholarship holder. In autumn 2013, she was a FIABCI scholar.

ORCID iD: http://orcid.org/0000-0002-0280-2977

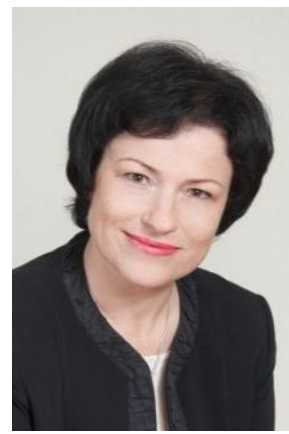

Ineta Geipele is a Professor of the Faculty of Engineering Economics and Management, Director of the Institute of Civil Engineering and Real Estate Economics, the Head of the Department of the Civil Construction and Real Estate Economics and Management at Riga Technical University, Latvia. She improved her professional skills in Austria, Germany, Denmark and the UK. Ineta Geipele is the author and co-author of more than 300 scientific publications. Her current research areas are sustainability development problems of real estate market, construction industry, land use management and institutional economics. Professor Ineta Geipele is an expert of the Latvian Academy of Sciences in Management and Economics Sciences at the Latvian Council of Science, a board member of the FIABCI-Baltic Multinational Chapter and of the Cunfte of the Facility Management of Latvian Housing, and a member of the Latvian Union of Civil Engineers.

ORCID iD: http://orcid.org/0000-0002-2963-087X 


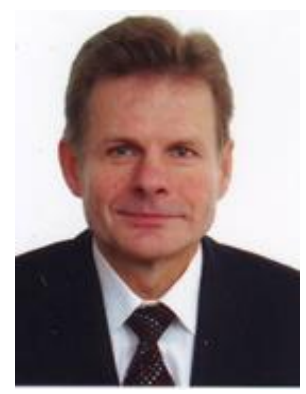

Jānis Vanags is a Professor of the Faculty of Engineering Economics and Management at Riga Technical University (RTU). He received the Doctoral degree in economics from RTU in 2004.

His research and teaching interests include national economics, engineering economics, building management, real estate economics, microeconomics and macroeconomics processes, real estate management, and sustainable development. At present, J. Vanags teaches undergraduate and postgraduate courses in national economics, finance market, and real estate economics at RTU.

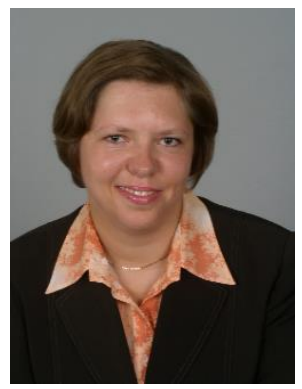

Natalija Lepkova, Doctor of technological sciences, Associate Professor at Vilnius Gediminas Technical University, Faculty of Civil Engineering, Department of Construction Management and Real Estate. She is an Editorial Board Member of Baltic Journal of Real Estate Economics and Construction Management.

Research areas: facilities management, real estate management, quality management systems, distance learning.

Participated in international projects, such as INTEREG Project Longlife, COST Project, etc. Author and co-author of several textbooks on facilities management and sustainable development and articles published in various national and international publications. Member of editorial board of the following journals: International Women Online Journal of Distance Education, Turkish Online Journal of Distance Education, GLOKALde - an official e-journal of UDEEEWANA-United Distance Education for Eastern Europe, Western Asia and Northern Africa.

E-mail: Natalija.Lepkova@vgtu.lt 